\title{
In-School Adolescents And Career Choice: The Case Of Ekiti State, Nigeria
}

\author{
E.O. Osakinle, University Of Ado-Ekiti, Nigeria
}

\begin{abstract}
This paper examines in-school adolescents and career choices in Ekiti State, Nigeria. The sample consists of two hundred randomly selected parents and in-school adolescents from four local government areas in Ekiti State. Two hypotheses were generated and tested at 0.05 level of significance using t-test statistical analysis. The results showed that there were no significant differences between parental influence, as well as gender influence of in-school adolescents in choice of career. The paper concludes that parents need to give adequate career information to their adolescents and have positive job values. Also, females need to decide whether to start their family first or settle on a career and start their family later.
\end{abstract}

Keywords: In-school, Adolescents, Career choice, Peers

\section{INTRODUCTION}

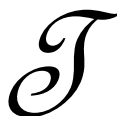

here are three main theories that describe the manners in which adolescents make choices about career development. These are: 1) Ginzberg's developmental theory, 2) Super's self-concept theory, and 3) Holland's personality type theory. The Ginzberg's developmental theory is Eli Ginzberg's theory that children and adolescents go through three choice stages; fantasy, tentative and realistic (Ginzberg, 1972; Ginzber, et $a l, 1951)$. When asked what they want to be when they grow up, young children may answer "a doctor", "an accountant", "a superhero", or "a sport star", but not many would say "a teacher". Ginzberg argues that, until about the age of 11, children are in the fantasy stage of career choice. From the ages of 11 to 17, adolescents are in the tentative stage of career development, while Ginzberg calls the period from 17 to 18 years of age through the early twenties the realistic stage of career choice.

The career self-concept theory is Donald Super's theory that an individual's self-concept plays a central role in his or her career choice. Super believes that it is during adolescence that individuals first construct a career self-concept (Super, 1967, 1976). Supers talks of the crystallization phase when the adolescent develops ideas about work that mesh with their already existing global self-concept. Next is the specification phase when the adolescents narrow down their choices and initiate behaviour that enables them to enter some type of career. The implementation phase is when the young adults complete their education or training and enter the world of work. The stabilization phase is when a specific, appropriate career is made and finally, when the individuals seek to advance their careers and to reach higher status positions. This phase is called consolidation.

Personality type theory is John Holland's theory that an effort should be made to match an individual's career choice with his/her personality (Holland, 1973, 1987). According to Holland, once individuals find a career that fits their personality, they are more likely to enjoy that particular career and to stay in a job for a longer period of time than individuals who work at jobs not suited to their personality. He talks of six basic personality types that need to be considered when matching the individuals' psychological make-up to a career. These are: Realistic, Investigative, Social Conventional, Enterprising and Artistic. However, one of the crucial aspects of planning in career development is awareness of the educational requirements for a particular career. From a study carried out by Grotevant and Durrett (1980), it was discovered that students lacked accurate information about two aspects of a career: 1) the educational requirements of careers they desired and 2) the vocational interest predominantly associated with their choices. From another study carried out by Schneider and Stevensen (1999), they discovered that adolescents were more ambitious in the 1990s than in the 1970s and 1980s and that the rising ambitions of 
adolescents were not confined to those from white middle-income families, but also characterized by adolescents from low-income and ethnic minority families. In some years back, both adolescents and their parents often failed to make meaningful connections between educational credentials and future work opportunities. Parents can improve this by becoming more knowledgeable about which courses their adolescents are taking in school, developing a better understanding of the college admissions process, providing adolescents with better information about various careers, and realistically evaluating their adolescents' abilities and interests in relation to these careers.

According to Osakinle and Adegoroye (2008), factors that influence adolescents' choice of career are sex, location of choice maker, environment, school influence (peer and curricular content), religious affiliation, child rearing, and family values. Also, mothers who work regularly outside the home and show effort in their work probably have strong influences on their adolescents' career choices. It could then be said that when both parents work and enjoy their work, adolescents learn work values from both parents. It was argued that the development of work value is transmitted more strongly in the same-sex parent adolescent relationship than in the opposite-sex parent-adolescent relationships. They also believe that the transmission of work values is more likely to occur in the father-son than in the mother-daughter relationship (Ryu and Mortimer, 1996). Parents potentially influence adolescents' occupational choices through the way they present information about occupations and values, as well as through the experiences they provide adolescents (Hargrove, Creagh and Burgess, 2003). For example, parents can communicate to their children and adolescents that they value the importance of going to college and attaining a professional degree as a means to attaining a career in Medicine, Law or business. Other parents might communicate that college is not as important and place a higher value on being a sports or movie star.

According to Berz (2002) and Gates (2001), they noted that many females have been socialized to adopt nurturing roles rather than career or achieving roles, that they traditionally have not planned seriously for careers, have not explored career options extensively, and have restricted their career choices to careers that are gender stereotyped. The motivation for work is the same for both sexes. However, female and males make different choices because of their socialization experiences and the ways that social forces structure the opportunities available to them.

As growing numbers of young women pursue careers, they tend to be faced with questions involving career and family: should they delay marriage and childbearing and establish their career first? Or should they combine their marriage and childbearing in their twenties? Some females in the last decade have embraced the domestic patterns of an earlier historical period. They have married, bore children and committed themselves to full-time mothers. These "traditional" females have worked outside the home only intermittently and have subordinated their work role to the family role.

\section{HYPOTHESES}

Two hypotheses were postulated for the study:

i. There is no significant difference between parental influence and in-school adolescent choice of career.

ii. There is no significant difference between gender and in-school adolescent choice of career.

It is to this end that the researcher wishes to investigate in-school adolescents and career choice: the case of Ekiti State, Nigeria.

\section{METHODOLOGY}

Ekiti State has 16 local government areas of which four were randomly selected. The population for the study comprised all parents and their children in secondary school in Ekiti State. Two hundred (200) samples from four local government areas were randomly selected from the population. The instrument for the study was a selfconstructed one titled: Career Choice among Adolescents and their Parents (CCAAP). The instrument consisted of three sections - A, B and C. Section A was on the bio-data of the samples, Section B was for the adolescents, and Section $C$ was for the parents. 
The questionnaire had 40 items that solicited information on career choices for both adolescents and their parents. The instrument had a validity coefficient of 0.76 and a reliability co-efficient of 0.85 . It was tested at 0.05 level of significance. The questionnaire were scored using a two-point scale of Yes/No with Yes allocated two (2) points and No allocated one (1) point.

\section{HYPOTHESES TESTING}

Hypothesis 1: There is no significant difference between parental influence and in-school adolescents' choices of career.

Table 1: t-test analysis showing parental influence and in-school adolescents choice of career

\begin{tabular}{|l|c|c|c|c|c|c|}
\hline \multicolumn{1}{|c|}{ Subjects } & $\mathbf{N}$ & $\mathbf{X}$ & $\mathbf{S D}$ & $\mathbf{D f}$ & t-cal & t-table \\
\hline Parent (male) & 121 & 52.74 & 6.94 & & 0.021 & \\
\\
\hline Parent (female) & 79 & 52.89 & 5.14 & 198 & (NS) & 1.96 \\
\hline
\end{tabular}

NB: NS = Not Significant at 0.05 level of significance

Table 1 shows that the number of male parents was 121 with a mean of 52.74 and a standard deviation of 6.94. The number of female parents was 79, the mean was 52.89, and the standard deviation was 5.14. Their degree of freedom was 198 . The t-cal (0.021) was less than t-table (1.96); hence, the hypothesis that there is no significant difference between parental influence and in-school adolescents' choice of career was accepted. This means that whether the parents were male or female did not really matter in their in-school adolescents' choice of career.

Hypothesis 2: There is no significant difference between gender and in-school adolescents' choice of career.

Table 2: t-test analysis showing gender and in-school adolescents choice of career

\begin{tabular}{|l|c|c|c|c|c|c|}
\hline \multicolumn{1}{|c|}{ Subjects } & $\mathbf{N}$ & $\mathbf{X}$ & SD & Df & t-cal & t-table \\
\hline Male & 110 & 53.14 & 6.83 & & 0.113 & \\
\\
Female & 90 & 52.33 & 7.50 & 198 & (NS) & 1.96 \\
\hline
\end{tabular}

NB: NS = Not Significant at 0.05 level of significance

Table 2 shows that the number of males was 110 with a mean of 53.14 and standard deviation of 6.83 , while the number of females was 90 with a mean of 52.33 and a standard deviation of 7.50. The degree of freedom was 198. The t-cal (0.113) was less than t-table (1.96); hence, the hypothesis that there is no significant difference between gender and in-school adolescents' choice of career was accepted. This means that whether the in-school adolescent was a male or female did not matter on their choice of career.

\section{DISCUSSION}

The findings revealed that the two hypotheses were accepted. The first hypothesis on the parental influence on adolescents' choice of career is supported by Osakinle and Adegoroye (2008) as they said child rearing and family values will influence adolescents' choices of careers and that adolescents learn work values from both parents, but transmission of work values is more likely to occur in the father-son rather than the mother daughter relationship. This is in agreement with the findings of Byu and Mortimer (1996). The way adolescents get career information from their parents would go a long way in helping adolescents make their choices of careers, which is in support of Hargrove, Creagh and Burgess, (2003).

For the second hypothesis regarding gender and in-school adolescents in choice of career, Betz (2002) agreed that females usually become socialized in things relating to family matters, like making children instead of choosing a career. Females usually face the problem of having to decide whether to delay their career and start a family later or choose a career first. Mothers who work regularly outside the home show effort and pride in their work and have a strong influence on their adolescents career choices (Osakinle and Adegoroye, 2008). 


\section{CONCLUSION AND RECOMMENDATION}

From this study, it could be concluded that both parents need to be good examples for their children in terms of their performance on the job since the adolescents learn a lot from them directly and indirectly. The parents need to be positive about their jobs since their adolescents are looking to them for their own careers. Furthermore, parents need to have enough information on the types of jobs available in order to help their adolescents choose their own careers.

It is therefore recommended that information needed by in-school adolescents needs to be given to them in such a way that they would be able to decide which of the careers they would want to go into. As parents, we need to be hard working because our children read both our expressed and unexpressed thoughts. As soon as our children choose their careers, we need to encourage them as much as possible so that they can prosper.

\section{AUTHOR INFORMATION}

Eunice O. Osakinle had her first degree in Education Language Arts from Ahmadu Bello University, Zaria. She had her second and third degrees in Education Guidance and Counseling from the University of Ado Ekiti, Nigeria. She has worked in several Institutions such as Christ's School, Ado Ekiti and The Federal Polytechnic, Ado Ekiti. She currently lectures in the Guidance and Counseling Dept. in the University of Ado Ekiti, Nigeria. She has written several Articles for both Local and International Journals. She has also attended local and international conferences. She is happily married with children and grandchildren.

\section{REFERENCES}

1. Betz, N. (2002). Explicating an ecological approach to the career development of women. Career Development Quarterly. 50, 335-338.

2. Gates, J. L. (2001). Women's career choices in Math and Science-related fields. Paper presented at the meeting of the society for Research in Child Development, Minneapolis.

3. Ginzberg, E. (1972). Toward a theory of occupational choice: A restatement. Vocational Guidance Quarterly, 20, 169-176.

4. $\quad$ Ginzberg, E., Ginzberg, S. W., Azelrad, S. and Herman, J. L. (1951). Occupational choice. New York: Columbia University.

5. Grotevant, H.D. and Durrett, M. E. (1980). Occupational knowledge and career development in Adolescence. Journal of Vocational Behaviour, 17, 171-182.

6. Hargrove, B. K., Greagh, M. G. and Burgess, R. L. (2003). Family interaction patterns as predictors of vocational identity and career decision-making self-efficacy. Journal of Vocational Behaviour, 61, 185201.

7. Holland, J. L. (187). Current status of Holland's theory of careers: Another perspective career Development Quarterly, 36, 24-30.

8. Holland, J. L. (1973). Making vocational choices. A theory of careers. Englewood Cliffs NJ. Prentice Hall.

9. Osakinle, E. O. and Adegoroye, B. S. (2008). Vocational Guidance and Career Counselling. Goldprints Publishers, Lagos Nigeria.

10. Ryu, S. and Mortimer, J. T. (1996). The "Occupational linkage hypothesis" applied to occupational value formation in adolescence. In J. T. Mortimer and M. D. Finch (Eds). Adolescents, work and family. An intergenerational development analysis. Understanding families, Vol. 6. Thousand Oaks CA: Sage.

11. Schneider, B. and Stvension, D. (1999) The ambitious generation. New Haven, C. T. Yale University.

12. Super, D. E. (1967). The psychology of careers. New York. Harper and Row.

13. Super, D. E. (1976). Career education and the meaning of work. Washington DC: U.S. Office of Education. 